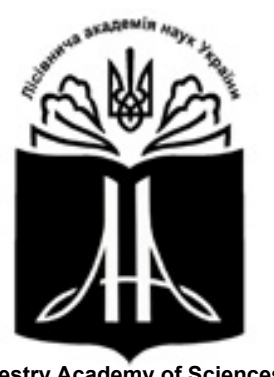

Forestry Academy of Sciences of Ukraine

Наукові праці Лісівничої академії наук України Proceedings of the Forestry Academy of Sciences of Ukraine

http://fasu.nltu.edu.ua https://doi.org/10.15421/411917

Article received 2018.09.20

Article accepted 2019.03.28
ISSN 1991-606X print

ISSN 2616-5015 online

(a) $\triangle$ Correspondence author

Lyudmyla Maksymiv maksymivl@ukr.net

General Chuprynka st., 103, Lviv, 79057, Ukraine

УДК 504.003.13:[620.9:630*812]

\title{
Еколого-економічна оцінка ефективності використання енергетичної деревини в регіональній агломерації «Дрогобиччина»
}

\author{
Л.І. Максимів ${ }^{1}$, Т.Р. Луцишин ${ }^{2}$
}

Агломераиія є територіальним об' 'єднанням різних населених пунктів, пов'язаних економічними, трудовими, соиіальними й іншими зв 'язками. Однією із найважливіших сфер, в якій потрібно налагодити тісну співпрачию в межах агломераиії, є підвищення енергоефективності. Особливістю регіональної агломераиії "Дрогобиччина» є її приналежність до Карпатського економічного району, який характеризується найвищою в Україні лісистістю і де місиеве населення традиџійно використовує деревину в енергетичних иілях для обігріву приміщень і приготування їжі. Відповідно тут є достатня кількість ресурсів деревної біомаси, яку можна і потрібно використовувати в енергетичних цілях, а також сприйняття иього виду палива як природного і прийнятного.

Карпатський регіон має значний потенціал деревної біомаси, доступної для енергетичного використання шляхом залучення лісової деревини, деревини від проведення ландщафтних робіт, залишків деревини від технічної обробки, деревних відходів. Додатковими джерелами деревного палива можуть бути парки, полезахисні лісосмуги, енергетичні плантаиії, лісонасадження уздовж автомобільних доріг $і$ залізниць, а також сухостій.

Ресурсний потениіал енергетичної деревини на території регіональної агломерації «Дрогобиччина» формують ресурси спеціалізованих підприємств, де головними постачальниками деревної біомаси є ДП «Дрогобицьке лісове господарство», Дрогобиџьке ДЛГП «Галсільліс» і потениійно КП «Зелений світ» ум. Борислав. У 2017 р. приріст деревини у лісовому фонді аналізованих підприємств становив: у ДП «Дрогобичьке ЛГ» - 113,4 тис. $^{3}$; Дрогобицькому ДЛГП «Галсільліс»-32,2 тис. м $^{3}$ КП «Зелений світ»-0,9 тис. м $^{3}$.

Резервом підвищення ефективності використання деревини є порубкові рештки, об'єм яких на зрубах ДП «Дрогобииьке ЛГ» у 2017 р. становив 7,1 тис. м $^{3}$ а на Дрогобицькому ДЛГП «Галсільліс» за перше півріччя 2018 р. - 0,5 тис. м․ Додатковим ресурсом деревної біомаси для використання в енергетичних иілях можуть слугувати відходи операиійної діяльності лісових господарств. Ще одним способом отримання деревної біомаси є вирощування енергетичних плантацій.

Для встановлення міри готовності місиевого населення використовувати деревину для опалення домогосподарств, а також чинників, які впливають на масштаби використання енергетичної деревини, було проведено соиіологічне опитування населення м. Борислав. 3'ясовано, що більшість жителів користуються індивідуальною системою опалення, використовуючи газ або комбіновані котли для опалення. Встановлено, що 40\% респондентів хотіли б змінити систему опалення. За сприятливих умов, таких як постійна наявність ресурсів, дешеві кредити на заміну системи опалення, субсидії на тверде паливо та активне просування деревної біомаси як джерела енергії, частина громадян висловила готовність перейти на опалювання житла енергетичною деревиною.

Ключові слова: регіональна агломераиія; енергетична деревина; деревні відходи; енергетичний потенціал; еколого-економічна ефективність.

Максимів Людмила Іванівна - член-кореспондент Лісівничої академії наук України, кандидат економічних наук, доцент кафедри екологічної економіки. Національний лісотехнічний університет України, вул. генерала Чупринки, 103, м. Львів, 79057, Україна. Тел.: +38 (032) 39-27-78. E-mail: maksymivl@ukr.net ORCID: https://orcid.org/0000-0001-5003-0249

2 Луцишин Тетяна Романівна - магістр економіки довкілля та природних ресурсів. Національний лісотехнічний університет України, вул. генерала Чупринки, 103, м. Львів, 79057, Україна. Тел.: +38-098- 649-64-61. E-mail: tetyana.lutsyshyn@ukr.net ORCID: https://orcid. org/0000-0001-6988-1545 
Вступ. Енергетика $є$ найголовнішою галуззю країни. Проте, внаслідок неефективної політики та інтенсивного використання невідновних ресурсів, Україна стала залежною від імпортованих газу, нафти та вугілля.

Серед найважливіших завдань реалізації цілей сталого розвитку України, зокрема цілі 7 «Доступна та чиста енергія» - збільшення частки енергії 3 відновлюваних джерел у національному енергетичному балансі. Досягнення цієї мети потребує створення умов для зростання виробництва енергії та iii доступного, надійного і сталого постачання споживачам; диверсифікації імпорту первинних енергоносіїв; збільшення виробництва і використання енергії з відновлюваних джерел, запровадження програм і заходів з підвищення енергозбереження й енергоефективності (Sustainable Development Goals: Ukraine, 2017).

Виробництво енергії $є$ основною темою дискусій стосовно зміни клімату, оскільки на нього припадає приблизно $60 \%$ викидів $\mathrm{CO}_{2}$ в атмосферу. 3 метою зменшення небезпечних викидів в атмосферу розвиток енергетики у XXI ст. відбувається в напрямі переходу до відновних джерел енергії. Альтернативними джерелами енергії $є$ сонячна, вітрова, геотермальна енергія, енергія хвиль, енергія 3 біомаси та ін.

Останніми роками в Україні спостерігається значний розвиток сонячної та вітрової галузей енергетики, тоді як генерування енергії з біомаси відбувається досить повільно. Використання деревної та аграрної (відходи сільського господарства) біомаси в енергетичних цілях, за оцінками експертів, $\epsilon$ надзвичайно перспективним заходом (Maksymiv, Klymovych, \& Zahvoyska, 2016, Debrynyuk, 2017, Geletukha, Kramar, Epic, Antoschuk, \& Titkov, 2016, Soloviy et al., 2019).

Близько 16\% території України вкрито лісами, а найбільш залісеним $€$ Карпатський регіон. Тому для забезпечення енергоефективності та енергонезалежності цього регіону варто розширити використання деревної біомаси, дотримуючись принципів сталого розвитку, беручи до уваги роль і функції лісових екосистем (Lutsyshyn \& Maksymiv, 2018, Pelyno \& Maksymiv, 2006).

Деревина $є$ відновним ресурсом і, незважаючи на забруднення повітря у процесі згорання, вважається вуглецево нейтральним ресурсом, адже у процесі росту дерева виділяють кисень, приносячи більше користі, ніж шкоди.

Високу актуальність теми дослідження зумовлюють три чинники: економічний, екологічний i політичний. Використання деревини як ресурсу для опалення органічно вписується в концепцію економіки замкнених циклів, чи, іншими словами, кругову економіку, яка на сьогодні $є$ такою лише на $9 \%$ (The Circularity Gap, 2019); екологічний чинник проявляється у дружньому до довкілля впливі енергетичної деревини; політичний чинник вбачається у збільшенні міри енергетичної незалежності України завдяки ширшому використанню місцевих від- новних ресурсів деревини. Окрім того, енергетична деревина $є$ ефективним засобом реалізації політики енергетичного переходу, який означає поступову заміну викопних видів палива для отримання енергії відновними, а також підвищення енергоефективності (Power system flexibility, 2018).

Дослідження здійснено у рамках виконання швейцарсько-українського проекту «Визначення можливостей зеленої енергії в Українських Карпатах» (2017-2020) під керівництвом Інституту снігу, лісу і ландшафтів (WSL) за фінансової підтримки Державного секретаріату з досліджень, освіти та інновацій Швейцарії (SBFI) (Bestimmung der Energieholzpotenziale, 2017) .

Об'єкти та методика дослідження. Об' $є к m$ дослідження - процес використання енергетичного потенціалу деревини. Предмет дослідження - еколого-економічна ефективність використання енергетичного потенціалу деревини в межах регіональної агломерації «Дрогобиччина». Мета роботи - розроблення рекомендацій щодо підвищення ефективності використання енергетичної деревини для забезпечення потреб населення на основі еколого-економічного аналізу ефективності використання енергетичної деревини в межах регіональної агломерації. Практичне значення отриманих результатів полягає у визначенні чинників впливу на підвищення ефективності використання енергетичного потенціалу деревної біомаси в межax регіональної агломерації.

Результати досліджень. Деревину вважають першим джерелом енергії для людства. Сьогодні вона залишається одним із найважливіших ресурсів для розвитку відновлюваної енергетики, становлячи близько $6 \%$ світової загальної первинної енергії. Більше двох мільярдів людей у світі залежать від енергії деревини для приготування їжі та опалення, особливо сільські домогосподарства в країнах, що розвиваються. Деревина для них є єдиним доступним джерелом енергії. Використання деревного палива в домогосподарствах для приготування їжі та опалення становить $1 / 3$ глобального споживання відновлюваної енергетики, що робить деревину найбільш децентралізованим видом енергії у світі (Wood Energy, 2017).

В останні десятиріччя попит на енергетичну деревину збільшився і в Європі. Експерти очікують подальшого зростання такого попиту у зв'язку 3 соціально-політичними змінами (Peters et al., 2015).

Енергетичний потенціал деревини та способи його використання. За даними Державної служби статистики України обсяги заготівлі ліквідної деревини 32000 до 2016 рр. зросли від 11,3 до 19,6 млн м $3 /$ рік, а обсяг заготівлі дров збільшився 3 4,1 до 6,9 млн м³/рік. Загалом існує тенденція до зростання обсягів заготівлі деревини.

Варто зазначити, що в Україні спостерігаються значні обсяги самозаготівлі деревини, які мають тенденцію до щорічного збільшення. Для прикладу, в 2013 р. вони становили 3,3, а в 2016 р. - вже 9,9 млн м³/рік. Це негативно впливає на економічне 
становище країни через появу нелегального ринку біопалива та створення нерівних умов для всіх учасників ринку (Geletukha, Zheliezna, Pastukh, \& Dragnev, 2018). Тільки у Львівській області в 2018 р. на перетворення в інші види палива та енергію було використано 239,2 тис. щільних м $^{3}$ дров для опалення, а стружки і тріски деревної - 36,4 т (State Statistics Service, 2018).

Заготівля деревини відбувається шляхом проведення рубок головного користування, формування i оздоровлення лісів та інших заходів, не пов'язаних 3 веденням лісового господарства. Базовими складниками потенціалу біомаси $є$ відходи сільського господарства та деревна біомаса. В Українських Карпатах деревна біомаса продукується домінантними смерековими, буковими та ялицевими лісами, меншою мірою - дубовими (Lakyda, Geletukha, \& Vasylyshyn, 2011). Деревину використовують у вигляді колод, полін, дров, стружки, тріски, тирси i пилу (для створення брикетів).

Дослідники (Burg, Bowman, Erni, Lemm, \& Thees, 2018) виділяють такі джерела деревної біомаси:

1) лісова енергетична деревина, заготовлена для виробництва енергії, куди відносять частини стовбурів, гілки дерев, хмиз і кору;

2) деревина, отримана від проведення ландшафтних рубок, під час обрізання і кронування дерев у парках, садах і придорожніх ділянках;

3) залишки деревини від технічної та технологічної обробки. Це рештки деревини (кора, тріска, стружка та пил) від виготовлення та переробки виробів 3 деревини (переважно лісопильні, деревообробні і столярні виробництва), яка з'являється в процесі виготовлення основної продукції;

4) відходи деревини. Це деревні відходи будівництва (після знесення, реконструкції); відходи дерев, пошкоджених шкідниками; деревина, отримана 3 великогабаритних відходів.
Останнім часом зростає попит на деревну біомасу як паливо, тоді як її технічний потенціал є обмеженим і вже майже повністю утилізується. Тому актуальним $є$ пошук і аналіз додаткових джерел деревного палива, серед яких може бути деревина iз полезахисних лісосмуг, лісонасаджень вздовж автомобільних доріг і залізниць, а також сухостій (Zheliezna, Bashtovyy, \& Geletukha, 2016).

За результатами конкурсу кращих практик використання енергетичної деревини, проведеного в рамках міжнародного проекту «Використання зеленої енергії в Українських Карпатах» у 2018 р., проект місцевого жителя стосовно вирощування енергетичної верби міжнародною конкурсною комісією було визнано одним із кращих (Soloviy et al., 2019).

Аналіз ресурсного потенціалу енергетичної деревини регіональної агломерації «Дрогобиччина». Ліси, відповідно до Лісового кодексу України, є власністю українського народу і можуть перебувати у приватній, комунальній та державній власності (Forest Codex, 1994). На території регіональної агломерації «Дрогобиччина» ліси знаходяться переважно у державній, частково - у комунальній власності (ліси на території населених пунктів). Господарську діяльність на цій території здійснює ДП «Дрогобицьке лісове господарство» і невеликі комунальні підприємства. Серед них, КП «Зелений світ» у м. Борислав із загальною площею комунальних лісів у 255 га, та Дрогобицьке ДЛГП «Галсільліс», яке здійснює господарську діяльність на площі 2,5 тис. га.

ДП «Дрогобицьке лісове господарство» провадить свою діяльність на території 29,9 тис. га, 3 яких лише $57 \%$ становлять експлуатаційні ліси, тоді як іншу частину території становлять захисні ліси, рекреаційно-оздоровчі ліси та ліси природоохоронного, наукового, історико-культурного призначення. Розподіл території підприємства за категоріями захисності наведено в табл. 1.

\section{Розподіл території ДП «Дрогобицьке лісове господарство» за категоріями захисності}

\begin{tabular}{|c|c|c|}
\hline Категорія захисності & Площа, га & Частка від загальної площі, \% \\
\hline $\begin{array}{l}\text { 1. Ліси природоохоронного, наукового, історико-культурного } \\
\text { призначення (заказники) }\end{array}$ & 2277,9 & 8 \\
\hline 2. Рекреаційно-оздоровчі ліси & 9825,5 & 33 \\
\hline 3. Захисні ліси & 691,8 & 2 \\
\hline 4. Експлуатаційні ліси & 17095,8 & 57 \\
\hline Всього & 29891,0 & 100 \\
\hline
\end{tabular}

Загальна площа території лісгоспу становить 29,9 тис. га, а площа земель, вкритих лісовою рослинністю - 27 тис. га. Основними лісотвірними породами $\epsilon$ дуб, ялиця, модрина, ялина, бук. Площа хвойних лісів займає 6,6 тис. га або $24,4 \%$ залісених територій. Площа твердолистяних порід становить 19,4 тис. га або 71,9\%. Найменша частка при- падає на м'яколистяні породи - близько 1 тис. га або $3,7 \%$.

Розподіл території ДП «Дрогобицьке ЛГ» за віковими і породними групами наведено у табл. 2.

Згідно з лісовпорядними документами (Description of the Haivs'kyy, 2016, Drohobych Forestry, 2016), середній приріст деревини у лісгоспі на 1 га 
у 2015 р. становив 4,0, у 2016 р. - 4,1 м³. Інформація за 2017 р. відсутня, тому вважатимемо, що середньорічний приріст зріс на $0,1 \mathrm{~m}^{3}$ на 1 га (оскільки зменшились обсяги лісозаготівлі) і становить
4,2 м³. Використавши дані попередніх таблиць, розрахуємо річний приріст деревини у лісах підприємства загалом та в експлуатаційних лісах - зокрема. Результати наведено в табл. 3 .

Таблиия 2

\section{Розподіл вкритих лісовою рослинністю ділянок ДП «Дрогобицьке лісове господарство»} за групами віку

\begin{tabular}{|c|c|c|c|c|c|}
\hline $\begin{array}{l}\text { Група віку, } \\
\text { група порід }\end{array}$ & $\begin{array}{l}\text { Площа, } \\
\text { га }\end{array}$ & $\begin{array}{l}\text { Частка від } \\
\text { загальної } \\
\text { площі, \% }\end{array}$ & $\begin{array}{l}\text { Група віку, } \\
\text { група порід }\end{array}$ & $\begin{array}{l}\text { Площа, } \\
\text { га }\end{array}$ & $\begin{array}{l}\text { Частка від } \\
\text { загальної } \\
\text { площі, \% }\end{array}$ \\
\hline Хвойні & & & М'яколистяні & & \\
\hline 1. Молодняки & 1617,2 & 6,0 & 1. Молодняки & 28,7 & 0,1 \\
\hline 2. Середньовікові & 2036,9 & 7,5 & 2. Середньовікові & 351,4 & 1,3 \\
\hline 3. Пристигаючі & 1450,9 & 5,4 & 3. Пристигаючі & 154,2 & 0,6 \\
\hline 4. Стиглі і перестійні & 1473,7 & 5,5 & 4. Стиглі і перестійні & 477,4 & 1,7 \\
\hline Разом & 6578,7 & 24,4 & Разом & 1011,7 & 3,7 \\
\hline Твердолистяні & & & Всього по лісгоспу & & \\
\hline 1. Молодняки & 1971,6 & 7,3 & 1. Молодняки & 3617,5 & 13,4 \\
\hline 2. Середньовікові & 10589,9 & 39,2 & 2. Середньовікові & 12978,2 & 48,1 \\
\hline 3. Пристигаючі & 4027,3 & 14,9 & 3. Пристигаючі & 5632,4 & 20,8 \\
\hline 4. Стиглі і перестійні & 2824,5 & 10,5 & 4. Стиглі і перестійні & 4775,6 & 17,7 \\
\hline Разом & 19413,3 & 71,9 & Всього & 27003,7 & 100,0 \\
\hline
\end{tabular}

Приріст деревини на території ДП «Дрогобицьке лісове господарство»

Таблиия 3 за період 2015-2017 pp.

\begin{tabular}{lcccc}
\hline \multicolumn{1}{c}{ Показник } & Одиниця & \multicolumn{3}{c}{ Рік } \\
\cline { 3 - 5 } & виміру & 2015 & 2016 & 2017 \\
\hline Приріст на 1 га & $\mathrm{M}^{3}$ & 4,0 & 4,1 & 4,2 \\
Загальний приріст & ${\text { тис. } \mathbf{M}^{3}}^{*}$ & 108,0 & 110,7 & 113,4 \\
Приріст деревини в експлуатаційних лісах & $\mathrm{M}^{3}$ & 61,6 & 63,1 & 64,6 \\
\hline
\end{tabular}

Основною причиною збільшення обсягів приросту є зменшення обсягів заготівлі деревини у 2016-2017 pp. У табл. 4 наведено обсяги заготівлі та реалізації деревини лісгоспом. Так, у 2015 р. було заготовлено 71,1 тис. $\mathrm{m}^{3}, 3$ них реалізовано 65,7 тис. м ${ }^{3}$ (залишилось $-5,4$ тис. $\mathrm{m}^{3}$ ), 3 яких 1,0 тис. $\mathrm{m}^{3}$ - ділової деревини, 1,2 тис. м $^{3}$ - дров'яної деревини, а на хлисти і напівхлисти припало 3,1 тис. $\mathrm{m}^{3}$.

У 2016 р. в лісгоспі заготовлено 68,0 тис. м ${ }^{3}$ деревини, а реалізували 60,5 тис. ${ }^{3}$. Залишки збільшились до 7,5 тис. м ${ }^{3}$, зокрема залишки ділової деревини зросли до 1,4, дров'яної деревини - до 1,4, хлистів і напівхлистів - до 4,7 тис. м². У 2017 р., порівняно з періодом 2015-2016 рр., зафіксовано нижчі обсяги заготівлі і реалізації деревини, а також суттєво зменшились залишки. Обсяги заготівлі становили 63,3 тис. $\mathrm{M}^{3}$, а реалізації- 58,9 тис. м³. Як і в попередні два роки, основну частину залишків становили хлисти і напівхлисти - 2,9 тис. м³ частину становила дров'яна деревина $-1,1$ тис. ${ }^{3}$, тоді як обсяги залишків ділової деревини суттєво

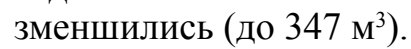

Потрібно зауважити, що впродовж аналізованого періоду інтенсивно велась заготівля деревини, у 2015-2016 рр. навіть перевищуючи обсяги приросту. Це свідчить про потребу в зменшенні антропогенного навантаження на довкілля та ефективнішого використання деревини.

Для підвищення ефективності використання деревини доцільно, на наш погляд, використати порубкові рештки, які потенційно можуть стати джерелом для виробництва тріски. За даними експертів БАУ (Geletukha, G. et al., 2018), їх обсяг складає близько $14 \%$ загального об'єму заготівлі ліквідної деревини, а близько $20 \%$ з них необхідно залишати в лісі для збереження біорозмаїття.

На підставі викладеного вище, приблизний об'єм залишків деревини (Оз) можна розрахувати, скоригувавши об'єм ліквідної деревини (Ол) за формулою:

$$
\text { Оз }=\text { Ол } \times 0,14 \times 0,8 .
$$

На основі даних табл. 3 розрахуємо обсяги порубкових решток, які потенційно можна використати: 
1. 2015 p.: $71103 \mathrm{M}^{3} \times 0,14 \times 0,8=7963,5 \mathrm{M}^{3}$;

2. 2016 p.: $67965 \mathrm{M}^{3} \times 0,14 \times 0,8=7612,1 \mathrm{M}^{3}$;

3. 2017 p.: $63251 \mathrm{M}^{3} \times 0,14 \times 0,8=7084,1 \mathrm{M}^{3}$.

Отже, завдяки використанню порубкових решток можна суттєво підвищити ефективність використання деревини.

Аналізоване лісове господарство спеціалізується на реалізації круглих лісоматеріалів, випуску пиломатеріалів обрізних і необрізних, внаслідок чого утворюються відходи. Актуальною є проблема поводження з відходами, тому технологія виробництва має бути спрямована на їх мінімізацію, а в перспективі - й до їх повної відсутності.

У табл. 4 наведено інформацію про утворення, використання і поставку відходів виробництва (лісових відходів). Впродовж аналізованого періоду кількість лісових відходів загалом зменшилась. У 2015 p. мало місце нераціональне поводження 3 відходами, які були знищені або вивезені на звалище, тоді як їх можна було передати суб'єктам підприємницької діяльності для використання. Впродовж наступних двох років лісгосп співпрацював 3 іншими підприємствами та передавав їм деревні відходи, проте значна частка все одно залишалась у розпорядженні ДП «Дрогобицьке ЛГ». Значні обсяги відходів свідчать про недосконалість політики поводження з відходами.

За наведеними у табл. 4 даними, у 2015 р. можна було б додатково використати $3556 \mathrm{~m}^{3}$ відходів, у 2016 p. $-3300 \mathrm{~m}^{3}$, а в 2017 p. $-3163 \mathrm{~m}^{3}$. Тому можна підсумувати, що управління відходами має потенціал для покращення та потребує змін, насамперед у напрямі збільшення обсягів постачання деревних відходів фізичним особам - суб'єктам підприємницької діяльності та покращення технологічних умов виробництва.

На території регіональної агломерації «Дрогобиччина» діє КП «Зелений світ», яке підпорядковується Бориславській міській раді та здійснює виробничу, науково-дослідницьку i комерційну діяльність 3 метою отримання прибутку шляхом виконання робіт із озелененням територій міста i підприємств, вирощування декоративних рослин, овочевих культур, кущів, дерев, садивного матеріалу (Statute, 2016). Загалом підприємство займається лісогосподарською діяльністю і захистом лісових насаджень.

Загальна площа лісового фонду, де КП «Зелений світ» здійснює господарську діяльність, становить 255 га, 3 них 210,8 га вкриті лісовою рослинністю ділянки. Розподіл земель, вкритих лісовою рослинністю, наведено у табл. 5 .

У 2017 р. відповідно до плану заходів з поліпшення санітарного стану лісів та збереження стійкості насаджень були здійснені рубки на площі 4,9 га. Такі заходи проводились вперше за останні 15 років.

Якщо вважати, що приріст у комунальному лісі м. Борислав такий же, як на території лісів ДП «Дрогобицьке ЛГ», тобто 4,2 м 3 на 1 га (станом на 2017 р.), то загальний приріст (Пз) становитиме:

$$
\Pi_{3}=210 z a \times 4,2 \mathrm{M}^{3}=882 \mathrm{M}^{3} .
$$

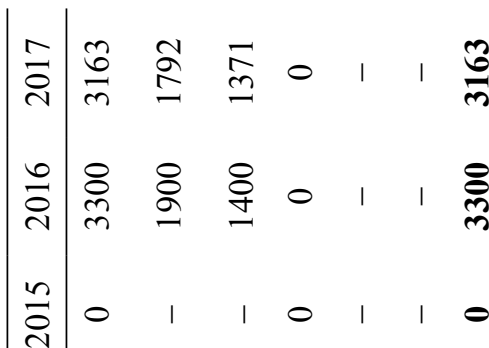

( 
Розподіл вкритих лісовою рослинністю земель КП «Зелений світ» за типами лісу, га

\begin{tabular}{|c|c|c|c|c|c|c|c|}
\hline \multirow[b]{2}{*}{$\begin{array}{l}\text { Індекс } \\
\text { типу лісу }\end{array}$} & \multirow[b]{2}{*}{$\begin{array}{c}\text { Переважаюча деревна } \\
\text { порода }\end{array}$} & \multicolumn{2}{|c|}{ Площа, га } & \multirow[b]{2}{*}{$\begin{array}{l}\text { Індекс } \\
\text { типу лісу }\end{array}$} & \multirow[b]{2}{*}{$\begin{array}{c}\text { Переважаюча } \\
\text { деревна порода }\end{array}$} & \multicolumn{2}{|c|}{ Площа, га } \\
\hline & & 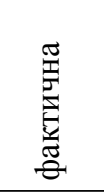 & 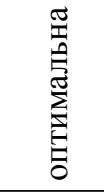 & & & 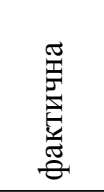 & 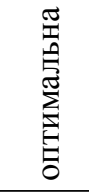 \\
\hline \multirow{13}{*}{$\mathrm{C}_{3}-б \kappa Я ц$} & Сосна звичайна & 4,9 & 4,9 & & Дуб звичайний & 2,1 & 3,4 \\
\hline & Ялина європейська & 0,8 & 0,8 & $\mathrm{C}_{3}$-яцД & Граб звичайний & 1,3 & - \\
\hline & Ялиця біла & 80,7 & 129,3 & & Разом & 3,4 & 3,4 \\
\hline & Модрина європейська & 3,4 & 3,4 & & Бук лісовий & 39,2 & 44,6 \\
\hline & Дуб червоний & 6,7 & 6,7 & & Клен-явір & 1,0 & 1,0 \\
\hline & Дуб звичайний & 0,9 & 0,1 & $\mathrm{C}_{3}$-яцБк & Береза повисла & 4,1 & - \\
\hline & Бук лісовий & 9,8 & 2,0 & & Вільха сіра & 1,3 & - \\
\hline & Граб звичайний & 2,1 & - & & Разом & 45,6 & 45,6 \\
\hline & Клен-явір & 3,2 & 3,2 & $\mathrm{C}_{4}$-Влч & Вільха чорна & 1,4 & 1,4 \\
\hline & Береза повисла & 22,6 & - & $\mathrm{C}_{4}-$ Влс & Вільха сіра & 10,0 & 10,0 \\
\hline & Осика & 6,5 & - & & Разом & 11,4 & 11,4 \\
\hline & Вільха сіра & 8,8 & - & & & & \\
\hline & Разом & 150,4 & 150,4 & & Усього & 210,8 & 210,8 \\
\hline
\end{tabular}

Оскільки останні 15 років лісовпорядні роботи у комунальних лісах не проводились, то там, за нашою оцінкою, зосереджена більша кількість біомаси, ніж у лісах, в яких постійно проводяться такі роботи. За значного нагромадження пошкодженої шкідниками та відмерлої деревини існує небезпека негативного впливу на здорові насадження, тому частину деревини варто вилучати та використовувати в енергетичних цілях.

Ще одним комунальним підприємством на території агломерації є Дрогобицьке ДЛГП «Галсільліс», загальна площа якого станом на 1.01 .12 р. становила 8,6 тис. га, з них 8,2 тис. га вкриті лісовою рослинністю ділянки. Розподіл території за категоріями захисності та групами віку наведено в табл. 6.

Якщо прийняти середньорічний приріст деревини аналогічним приросту ДП «Дрогобицьке ЛГ», то приріст на Дрогобицькому ДЛГП «Галсільліс» у 2017 р. становив:

1) загальний приріст (Пз):

$$
\Pi_{3}=8152,5 \text { гa } \times 4,2 \mathrm{M}^{3}=32240,5 \mathrm{M}^{3} ;
$$

2) приріст деревини в експлуатаційних лісах (Пе):

$$
\Pi e=8152,5 \text { га } \times 0,636 \times 4,2 \mathrm{M}^{3}=21776,9 \mathrm{M}^{3} .
$$

Дрогобицьке ДЛГП «Галсільліс» за перше півріччя 2018 р. здійснило рубки на площі 136,0 га із загальним обсягом заготовленої деревини $5068 \mathrm{~m}^{3}$, у т. ч. ліквідної - 4376 м³ $^{3}$ Відповідно, об'єм деревних відходів становив $692 \mathrm{~m}^{3}$, проте під час лісозаготівлі утворились додаткові відходи, які можна використати як біомасу. Розрахувати їх можемо за формулою 1, тоді об'єм порубкових решток $(O p)$ за перше півріччя 2018 р. становитиме:

$$
O p=4376 \boldsymbol{M}^{3} \times 0,14 \times 0,8=490,1 \boldsymbol{M}^{3} .
$$

Таблиия 6

\begin{tabular}{|c|c|c|c|c|c|}
\hline \multicolumn{6}{|c|}{ Розподіл лісових територій за: } \\
\hline \multicolumn{3}{|c|}{ категоріями захисності } & \multicolumn{3}{|c|}{ віковими групами } \\
\hline Категорія захисності & Площа, га & $\begin{array}{l}\text { Частка від } \\
\text { загальної } \\
\text { площі, \% }\end{array}$ & Вікова група & Площа, га & $\begin{array}{l}\text { Частка від } \\
\text { загальної } \\
\text { площі, \% }\end{array}$ \\
\hline Рекреаційно-оздоровчі ліси & 118,2 & 1,4 & Молодняки & 1388,7 & 17,0 \\
\hline Захисні ліси & 3019,6 & 35,0 & Середньовікові & 4522,9 & 55,5 \\
\hline \multirow{2}{*}{ Експлуатаційні ліси } & \multirow{2}{*}{5495,0} & \multirow{2}{*}{63,6} & Пристигаючі & 1628,6 & 20,0 \\
\hline & & & Стиглі і перестійні & 612,3 & 7,5 \\
\hline Всього & 8632,8 & 100,0 & Всього & 8152,5 & 100,0 \\
\hline
\end{tabular}

\section{Розподіл територій Дрогобицького ДЛГП «Галсільліс» за категоріями захисності та групами віку (General information, 2018)}


Отже, ефективність роботи підприємства загалом можна підвищити за рахунок ефективнішого використання відходів деревини.

Аналізуючи діяльність ДП «Дрогобицьке ЛГ», КП «Зелений світ» і КП Дрогобицьке ДЛГП «Галсільліс», можна підсумувати, що на території регіональної агломерації «Дрогобиччина» $є$ значні ресурси енергетичної деревини і вони потребують ефективнішого використання. Підвищити ефективність використання потенціалу енергетичної деревини підприємств можна завдяки спільним зусиллям і спільним проектам у межах агломерації «Дрогобиччина».

Еколого-економічна оцінка впливів проектів спільного використання енергетичної деревини. Підвищення енергоефективності сьогодні важливе як для місцевих жителів та підприємств, так і для країни загалом. Зробити міста дійсно енергоефективними можливо лише за умови використання місцевих ресурсів, зокрема, деревної біомаси.

Регіональна агломерація «Дрогобиччина» знаходиться в Прикарпатті (історико-етнографічний район України) і має всі передумови для використання енергетичної деревини. Як було згадано вище, діючі на цій території лісогосподарські підприємства ДП «Дрогобицьке ЛГ», КП «Зелений світ» і КП Дрогобицьке ДЛГП «Галсільліс» є основними постачальниками деревної біомаси і за тісної співпраці можуть покращити свою діяльність і сприяти енергонезалежності громад, які входять до складу агломерації.

Спільні енергетичні проекти можуть охоплювати такі аспекти: ефективне використання приросту деревини, порубкових решток, відходів операційної діяльності, пошкодженої шкідниками або непридатної деревини (сухостою), заготовленої під час санітарних рубок, відходів від рубок догляду у полезахисних смугах, лісонасадженнях уздовж доріг, місцевих парках; створення енергетичних плантацій.

Енергетична деревина $є$ одним із найдоступніших паливних ресурсів у Дрогобицькому районі, тому місцева влада повинна брати це до уваги під час прийняття рішень щодо реалізації проектів, пов'язаних з використанням деревини в енергетичних цілях. Проте, перш ніж запроваджувати такі проекти, варто дослідити, чи вони можуть задовольнити потреби місцевого населення та чи готові жителі перейти на використання деревного палива.

Очінка готовності жителів невеликих міст $i$ пристосованості їх помешкань до використання енергетичної деревини. Для того, щоб зрозуміти, наскільки пристосовані системи опалення місцевих домогосподарств до використання деревини як палива, оцінити рівень задоволеності наявною системою опалення, а, відповідно, і готовності до заміни систем опалення, було проведено опитування серед жителів м. Борислав. В опитуванні взяв участь 81 респондент, всі респонденти відповіли на запитання розробленої авторами анкети.

У м. Борислав налічується близько 6000 квартир і 4000 особняків. Оскільки нас цікавили різні типи домогосподарств, вибірка була суцільною, а опитування проводили серед жителів міста, які є власниками як квартир, так і особняків. Єдиною вимогою до респондентів було те, щоб кожен з них представляв окреме домогосподарство. Опитування двох і більше членів однієї сім'ї не практикувалось.

Більшість анкет було заповнено в процесі усного опитування - інтерв'ю (65 анкет), решта були заповнені респондентами під час онлайн-опитування.

Аналізуючи результати дослідження, було встановлено, що більшість респондентів проживає в квартирах, серед них переважають жителі квартир площею від 50 до 100 м², що відображено на рис. 1.

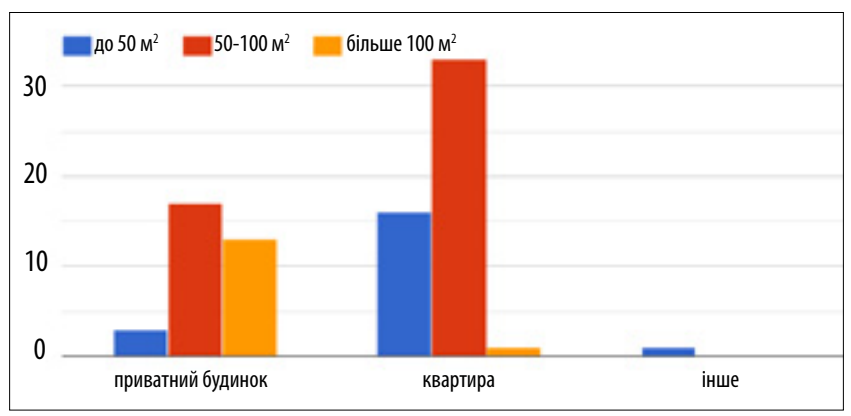

Рис. 1. Розподіл респондентів відповідно до характеристик їхнього житла

Характеризуючи систему опалення у їхніх помешканнях, 62 (77\%) респонденти вказали, що користуються індивідуальним опаленням, а інші 19 (23\%) респондентів отримують теплоенергію завдяки системі централізованого теплопостачання. Зазначимо, що до складу КП «Бориславтеплоенерго» входять дві котельні на твердому паливі та сім котелень на природному газі (Appeal of Deputies, 2018). За даними КП «Бориславтеплоенерго», на опалювальний сезон 2017-2018 рр. для потреб двох котелень було закуплено понад $500 \mathrm{~m}^{3}$ дров у Дрогобицькому та Самбірському лісгоспах, 3 яких використано близько $460 \mathrm{~m}^{3}$. Також серед жителів міста існує тенденція до переходу на індивідуальне опалення, тому з кожним роком комунальне підприємство обслуговує дедалі меншу кількість домогосподарств. Останні 10 років у місті поетапно виводять 3 експлуатації котельні, оскільки під час надання послуг теплопостачання відбуваються значні втрати енергії і вони є збитковими.

Серед респондентів 3 індивідуальною системою опалення найбільшу частку займають домогосподарства 3 системами на базі котлів (55\%). Також значна кількість населення має комбіновану систему опалення $(24 \%)$. Під комбінованою системою опалення розуміють поєднання кількох систем, таких як котли, конвектори, «теплі підлоги», печі, каміни. Однаковою $є$ частка жителів, які використовують конвектори та печі або каміни (10\%).

Отже, за результатами відповідей на друге питання стає зрозуміло, що більшість населення використовує індивідуальну систему опалення та віддає перевагу системі на базі котлів і комбінованій системі опалення. Результати відображено на рис. 2. 


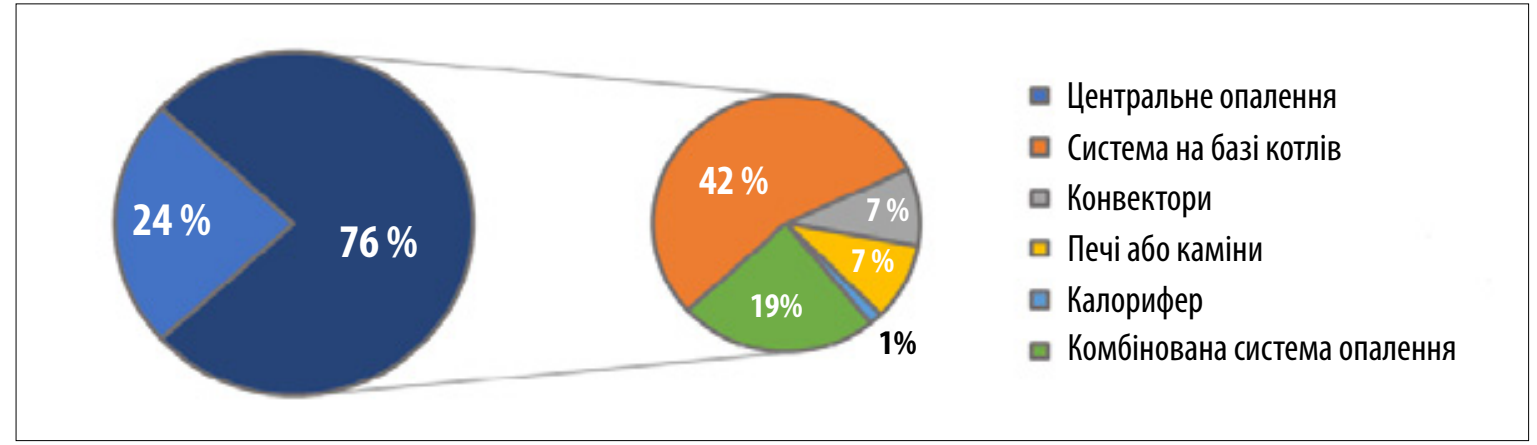

Рис. 2. Характеристика систем опалення

Більшість жителів користується індивідуальним опаленням, проте для них головним енергетичним ресурсом є газ. Невелика кількість респондентів використовує для опалення дрова та електроенергію: 3,7\% і 4,9\% відповідно. Значна частина місцевих жителів віддає перевагу комбінованому використанню ресурсів (дрова і газ; газ і електроенергія; газ, дрова і електроенергія), серед них найпоширенішим є використання газу і дров (рис. 3).

Більшість опитаних витрачає на опалення житла до 1000 грн на місяць, а також значна частина витрачає від 1000 до 2000 грн. Меншість респондентів (10 осіб) не змогли назвати суму витрат на опалення їхніх домогосподарств (рис. 4).

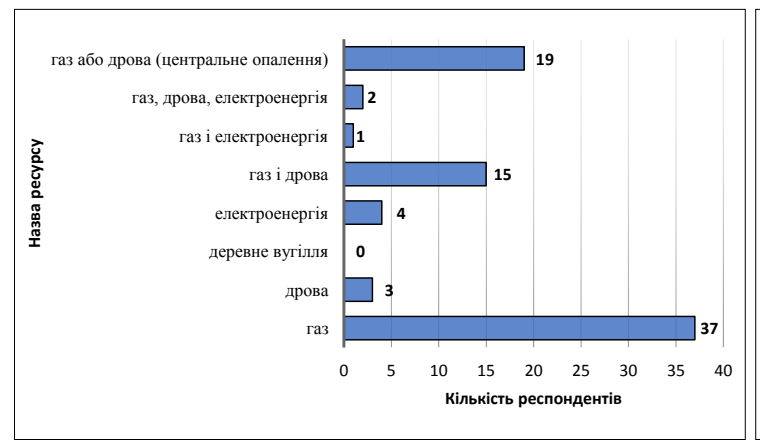

Рис. 3. Види енергетичних ресурсів, які респонденти використовують для обігріву житла

Найскладнішим для респондентів виявилося питання стосовно кількісних показників витрат (м³, кВт-год.) на обігрів житла. Значна частина респондентів не змогла відповісти однозначно, тому такі відповіді не враховуємо, оскільки оцінка обсягів використання ресурсів не може бути адекватною.

Серед опитаних 48 (59\%) осіб мали субсидії, а інші 33 (41\%) особи в період опалювального сезону 2017-2018 рр. субсидій не мали, що вказує на значні видатки 3 боку держави на покриття субсидій та низький рівень якості життя населення (рис. 5).

Серед опитаних місцевих жителів переважно задоволеними власною системою опалення є 45 осіб, тоді як 18 осіб - не задоволені і така ж кількість людей вагається в оцінці рівня задоволеності системою опалення (рис. 6).

За результатами опитування встановлено, що більшість жителів не хочуть змінювати систему опалення житла, проте $40 \%$ опитаних хотіли б i змінити (рис. 7).

Аналіз розподілу доходів по домогосподарствах показав наступне (рис. 8). Середньомісячний дохід домогосподарств респондентів переважно не біль-

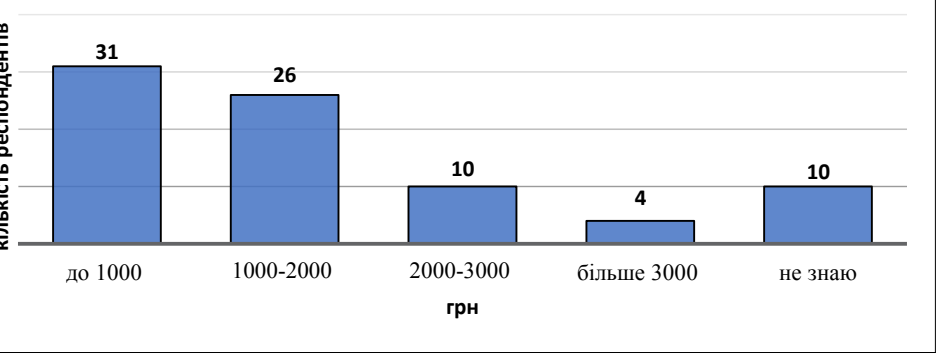

Рис. 4. Середньомісячні витрати на опалення

ший, ніж 15000 грн, тоді як частка домогосподарств 3 доходом від 5000 до 10000 грн є найвищою. Також часто трапляються домогосподарства 3 доходом до 5000 грн (рис. 8).

Шляхи впровадження проекту спільного використання деревини. Сьогодні на порядку денному стоїть завдання становлення енергонезалежності в Україні, тому держава намагається підтримувати проекти, пов'язані з відновлювальними джерелами енергії. Державне агентство 3 енергоефективності України (State Agency on Energy Efficiency, 2018) здійснює роботу щодо створення переліку проектів, які можуть бути презентовані інвесторам, зокрема, під час проведення офіційних міжнародних заходів. Беручи до уваги переваги використання деревини у межах агломерації, такий проект має всі шанси отримати підтримку агентства у пошуку інвесторів.

Також підвищенню інвестиційної привабливості Львівщини та залученню інвесторів сприяють регіональні органи управління. У 2016 р. почав працювати департамент із залучення інвестицій ЛОДА, який пропонує супровід інвестора на всіх етапах створення бізнесу та підтримку у вирішенні конфліктних питань. 


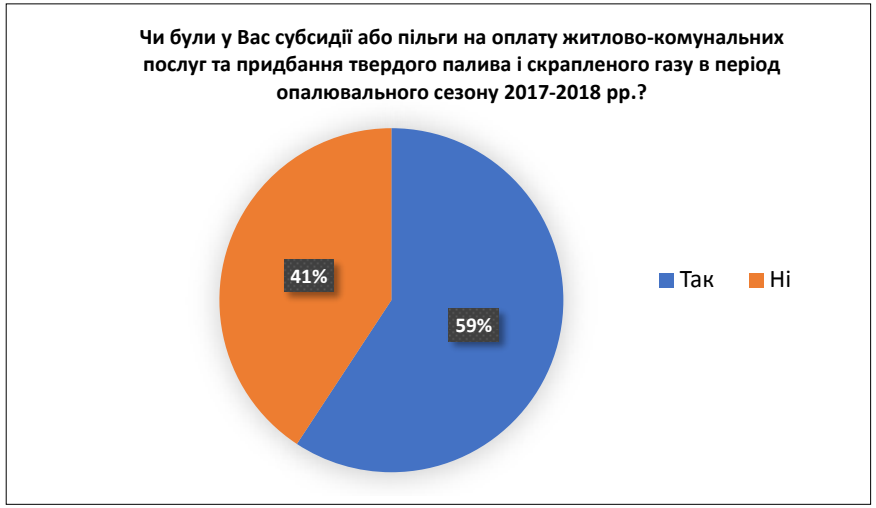

Рис. 5. Співвідношення респондентів за ознакою, які отримували чи не отримували субсидії

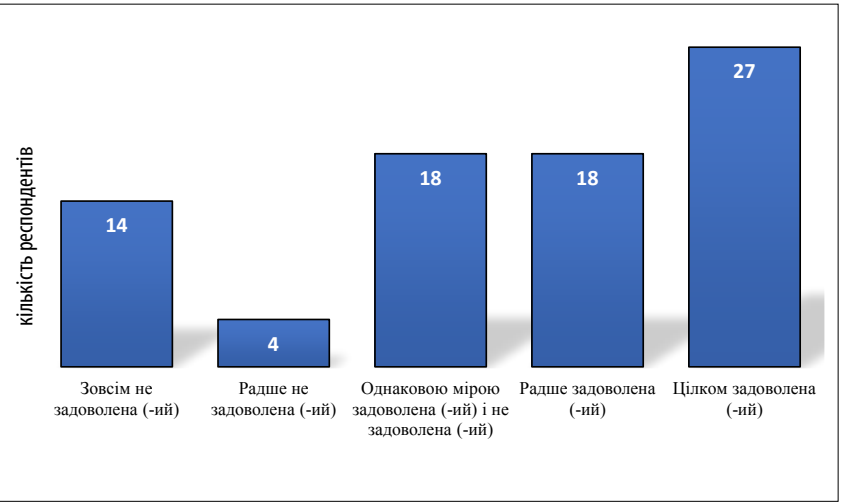

Рис 6. Рівень задоволеності респондентів системою опалення домогосподарства

\section{Чи хотіли б Ви замінити систему опалення Вашого житла?}

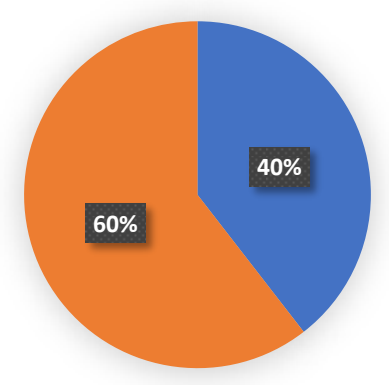

Рис. 7. Співвідношення респондентів стосовно їх бажання чи небажання змінювати систему опалення

Одним із способів залучення інвестицій $є$ подання заявок проектів на гранти, що актуально для регіональної агломерації «Дрогобиччина». Оскільки в Україні відбуваються процеси децентралізації і формуються об'єднані територіальні громади (ОТГ), для агломерації існує більше можливостей отримати грант на реалізацію проекту, оскільки проект спільного використання деревної біомаси в енергетичних цілях приноситиме прибуток, сприятиме забезпеченню населення місцевим відновлювальним джерелом енергії, ще й сприятиме зменшенню кількості відходів.

Висновки. Запаси деревини в Україні щороку зростають, як і обсяги ії заготівлі. У лісистих регіонах України доцільно використовувати деревину в енергетичних цілях для покриття потреб місцевого населення, дотримуючись принципів сталого розвитку. Забезпечення деревною біомасою відбувається шляхом залучення лісової деревини, деревини від проведення ландшафтних робіт, залишків деревини від технічної і технологічної обробки, деревних відходів. Додатковими об'єктами для заготівлі ураженої шкідниками та хворобами деревини можуть бути парки, полезахисні лісосмуги, лісонасадження уздовж автомобільних доріг і залізниць. Вагоме місце в цьому напрямі займають енергетичні плантації.

Використання енергетичної деревини має як економічні, так і екологічні вигоди. До екологічних

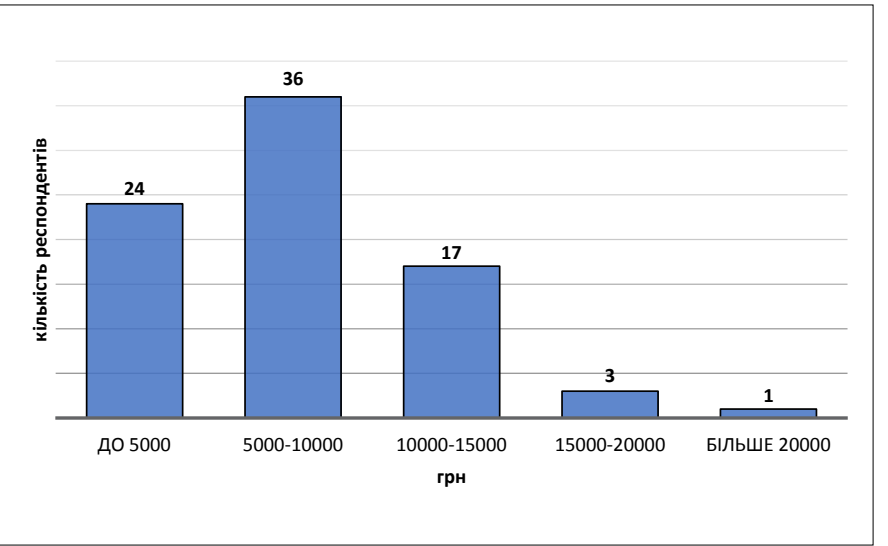

Рис. 8. Рівень доходів домогосподарств респондентів

належать: зменшення кількості деревних відходів; використання деревини як вуглецево нейтральної сировини та відновлюваного джерела енергії. Серед економічних вигід варто відзначити розширення бренду, мінімізацію витрат на утилізацію відходів, оптимізацію витрат на паливо, підвищення рівня енергонезалежності, простоту зберігання дров'яної сировини.

Ефекти від виробництва та використання енергетичної деревини необхідно враховувати під час формування лісової політики та сталого менеджменту лісів, беручи до уваги поточні та майбутні компроміси і розкриття всього потенціалу синергетичного ефекту, пов'язаного з іншими лісовими екосистемами.

Головними постачальниками деревної біомаси в регіональній агломерації «Дрогобиччина» ДП «Дрогобицьке ЛГ», Дрогобицьке ДЛГП «Галсільліс» та потенційно може стати КП «Зелений світ» у м. Бориславі. За нашими оцінками, приріст деревини на вкритих лісовою рослинністю ділянках у 2017 р. становив: у ДП «Дрогобицьке ЛГ»113,4 тис. м ${ }^{3}$, Дрогобицьке ДЛГП «Галсільліс» 32,2 тис. м $^{3}$, КП «Зелений світ» - 0,9 тис. м $^{3}$.

Ефективність використання деревини можна підвищити завдяки залученню порубкових решток, об'єм яких на ДП «Дрогобицьке ЛГ» у 2017 р. становив 7,1 тис. м³, а на Дрогобицькому ДЛГП «Галсіль- 
ліс» за перше півріччя 2018 p. - 0,5 тис. м³. Додатковим ресурсом деревної біомаси в енергетичних цілях можуть стати відходи операційної діяльності лісових господарств, а також деревна біомаса, отримана завдяки вирощуванню енергетичних плантацій.

Найефективніше використання деревної біомаси в енергетичних цілях можна забезпечити за умови співпраці лісогосподарських підприємств, розташованих на території агломерації.

За результатами дослідження готовності мешканців Борислава використовувати енергетичну деревину з'ясовано, що більшість жителів користуються індивідуальною системою опалення, в той же час значна частина бажає їі замінити (40\%). Вважаємо, що за наявності сприятливих умов - постійна наявність ресурсів, дешеві кредити на заміну системи опалення, субсидії на тверде паливо та активне просування деревної біомаси як джерела енергії - частина 3 них перейде на опалювання житла енергетичною деревиною.

Сьогодні існують сприятливі можливості для інвестування проектів спільного використання енергетичної деревини, враховуючи їх екологоекономічні впливи, а також вигоди (ринково оцінені та неоцінені), як з боку державних інституцій, так і міжнародних донорів. Вважаємо за доцільне створити і реалізувати такий проект у регіональній агломерації «Дрогобиччина».

\section{Бібліографічні посилання}

Appeal of Deputies of Boryslav City Council on the Financial and Economic Condition of the Boryslavteploenergo Utility Enterprise. Retrieved from http://www.boryslavmvk. gov.ua/5087-201707-031 (in Ukrainian).

Bestimmung der Energieholzpotenziale in den Ukrainischen Karpaten (2017). Retrieved from https://www.wsl.ch/de/projekte/energiepotenzialeukraine.html

Burg, V., Bowman, G., Erni, M., Lemm, R., \& Thees, O. (2018). Analyzing the potential of domestic biomass resources for the energy transition in Switzerland. Biomass and bioenergy, 111, 60-69. https://doi. org/10.1016/j.biombioe.2018.02.007

Debrynyuk, Yu. M. (2017). Plantation forestry and energy plantations in Ukraine: resource potential and development prospects. Scientific bulletin of the Ukrainian National Forestry University, 27 (8), 4551. https://doi.org/10.15421/40270806

Description of the Haivs'kyy Forestry activity (2018). Retrieved from http://forest. drohobych. net/opisdiyalnosti-gaïvskogo-lisnictva (in Ukrainian).

Drohobych Forestry State Enterprise activity (2016). Retrieved from http://forest. drohobych.net/diyalnistdp-drogobicke-lisove-gospodarstvo/ (in Ukrainian).

Drohobych Forestry State Enterprise (2018). Retrieved from www.logoskiev.com.ua/ books/ lisoteh/226.pdf (in Ukrainian).
Drohobych Forestry Enterprise «Halsillis». Forestry (2019). Retrieved from https://drohobych.lis. co.ua/napriamy-diialnosti/lisove-hospodarstvo (in Ukrainian).

Forest Code of Ukraine (1994). Retrieved from http://zakon.rada.gov.ua/laws/show/3852-12 (in Ukrainian).

Geletukha, G., Zheliezna, T., Pastukh, A., \& Dragnev, S. (2018) Opportunities for harvesting wood fuel in the forests of Ukraine. - 19th Position Paper of UABio, Retrieved from http://www.uabio.org/img/files/docs/ position-paper-uabio-19-en.pdf

Geletukha, G., Kramar, V., Epic, O., Antoschuk, T., \& Titkov, V. (2016) Comprehensive analysis of the Ukrainian biomass pellets market. Kyiv: Scientific and Technical Center «Biomass» (in Ukrainian).

General information of Drohobych Forestry «Halsillis» (2018). Retrieved from https:// drohobych.lis.co.ua/ pro-nas/zahalna-informatsiia (in Ukrainian).

Lakyda, P., Geletukha, G., \& Vasylyshyn, R. (2011). Energy biomass potential in Ukraine. Kyiv: National University of Life and Environmental Sciences of Ukraine Publishing House of Ukraine (in Ukrainian).

Lutsyshyn, T., \& Maksymiv, L. (2018) The potential of energy wood usage in the Ukrainian Carpathians: Problems and Perspectives. Proceedings of the 70th scientific-technical conference of the students, PhD students and students of the Small Academy of Ukrainian National Forestry University. Lviv (in Ukrainian).

Maksymiv, L., Klymovych, V., \& Zahvoyska, L. (2016). The potential of energy wood usage: ecological economics dimension. Proceedings of the Forestry Academy of Science of Ukraine, 14, 244251. Retrieved from http://fasu.nltu.edu.ua/index. php/nplanu/article/view/81/47 (in Ukrainian).

Pelyno, L., \& Maksymiv, L. (2006). The role of forest and the problem of accounting of the forest resources of Ukraine. Scientific Bulletin of Ukrainian National Forestry University, 16.3, 25-29. Retrieved from https://cyberleninka.ru/article/v/znachennya-lisivta-problemi-obliku-lisovih-resursiv-v-ukrayini (in Ukrainian).

Peters, D.M., Wirth, K., Böhr, B., Ferranti, F., Mifsud, E. C., Kärkkäinen, L., ... Zadnik Stirn, L. (2015). Energy wood from forests - stakeholder perceptions in five European countries. Energy, Sustainability and Society. 5-17. https://doi.org/10.1186/s13705015-0045-9

Power system flexibility for the energy transition (2018). Retrieved from file: ///C:/Users/ moyo/Downloads/IRENA_Power_system_ flexibility_1_2018.pdf

Statute of the municipal enterprise «Green World» of the Boryslav City Council (2016). Boryslav (in Ukrainian).

Soloviy, I., Melnykovych, M., Björnsen Gurung, A., Hewitt, R. J., Ustych, R., Maksymiv, L., Brang, P., Meessen, H., \& Kaflyk, M. (2019). Innovation in the use of wood energy in the Ukrainian Carpathians: 
Opportunities and threats for rural communities. Forest Policy and Economics, 104, 160-169. https:// doi.org/10.1016/j.forpol.2019.05.001

State Agency on Energy Efficiency and Energy Saving of Ukraine (2018). Retrieved from http://saee.gov.ua/ $\mathrm{uk} /$ business/investyscii (in Ukrainian).

State Forest Resources Agency of Ukraine (2019). General characteristics of forests of Ukraine. Retrieved from http://dklg.kmu.gov.ua/forest/control/ uk/publish /article?art_id $=62921 \&$ cat_id $=32867$ (in Ukrainian).

State Statistics Service of Ukraine (2019). Fuel briquettes and granules of wood and other natural raw materials. Retrieved from http://www.ukrstat. gov.ua/ (in Ukrainian).

Sustainable Development Goals: Ukraine. Baseline National Report (2017). Retrieved from http:// www.ua.undp.org/content/ukraine/en/home/library/ sustainable-development-report/sustainabledevelopment-goals--2017-basseline-national-report. html

The Circularity Gap Report (2019). Retrieved from https://www.circularity-gap.world/

Wood Energy. Food and Agriculture Organization of the United Nations (2017). Retrieved from http:// www.fao.org/forestry/energy/en/.

Zheliezna, T.A., Bashtovyy, A.I., \& Geletukha, G. G. (2016). Analysis of possibility to obtain wood fuel from additional sources in Ukraine. Industrial heat engineering, 38 (4), 71-77. Retrieved from http:// dspace.nbuv.gov.ua/handle/ 123456 789/142297

\section{Эколого-экономическая оценка эффективности использования энергетической древесины в региональной агломерации «Дрогобыччина»}

\section{Л.И. Максымив ${ }^{1}$, Т.Р. Луцишин ${ }^{2}$}

\begin{abstract}
Агломерация является территориальным объединением различных населенных пунктов с тесными экономическими, трудовыми, социальными и другими связями. Одна из важнейших сфер для налаживания тесного сотрудничества в рамках агломерации - повышение энергоэффективности. Особенностью региональ-
\end{abstract}

\footnotetext{
Максымив Людмила Ивановна - член-корреспондент ЛАН Украины, кандидат экономических наук, доцент кафедры экологической экономики. Национальный лесотехнический университет Украины, ул. генерала Чупрынки, 103, г. Львов, 79057, Украина. Тел.: +38 (032) 39-27-78. E-mail: maksymivl@, ukr.net ORCID: https://orcid.org/0000-0001-5003-0249

Луцишин Татьяна Романовна -магистр экономики окружающей среды и природных ресурсов. Национальный лесотехнический университет Украины, ул. генерала Чупрынки, 103, г. Львов, 79057, Украина. Тел.: (098) 6496461 : tetyana.lutsyshyn@ukr.net ORCID: https://orcid.org/0000-0001-6988-1545
}

ной агломерации «Дрогобыччина» является ее принадлежность к Карпатскому экономическому району, характеризующемуся наивысшей в Украине лесистостью, где местное население традиционно использует древесину в энергетических целях для обогрева помещений и приготовления пищи. Соответственно здесь имеется достаточное количество ресурсов древесной биомассы, которую можно и нужно использовать в энергетических целях.

Карпатский регион имеет значительный потенциал древесной биомассы, доступной для энергетического использования путем привлечения лесной древесины, древесины от проведения ландшафтных работ, остатков древесины от технической обработки, древесных отходов. Дополнительными источниками древесного топлива могут быть парки, полезащитные лесополосы, энергетические плантации, лесонасаждения вдоль автомобильных и железных дорог, а также сухостой.

Ресурсный потенциал энергетической древесины региональной агломерации «Дрогобыччина» формируют ресурсы специализированных предприятий, где главными поставщиками древесной биомассы является государственное предприятие «Дрогобычское лесное хозяйство», Дрогобычское государственное лесохозяйственное предприятие «Галсильлис» и коммунальное предприятие «Зеленый мир» в г. Борислав. В 2017 г. прирост древесины в лесном фонде предприятий составил: в ГЛП «Дрогобычское ЛХ»113,4 тыс. м ${ }^{3}$, Дрогобычского ГЛХП «Галсильлис» 32,2 тыс. м³

Резервом повышения эффективности использования древесины являются порубочные остатки, объем которых на ГП «Дрогобычское ЛХ» в 2017 г. составил 7,1 тыс. м $^{3}$, а на Дрогобычском ГЛХП «Галсильлис» за первое полугодие 2018 г. 0,5 тыс. м ${ }^{3}$. Дополнительным ресурсом древесной биомассы для использования в энергетических целях могут стать отходы операционной деятельности лесных хозяйств. Еще одним способом получения древесной биомассы является выращивание энергетических плантаций.

Для установления степени готовности местного населения использовать древесину для нужд домохозяйств, а также факторов, влияющих на масштабы использования энергетической древесины, был проведен социологический опрос части населения г. Борислав, в котором принял участие 81 респондент. В процессе исследования установлено, что большинство жителей пользуются индивидуальной системой отопления, используя газ или комбинированные котлы. Установлено, что $40 \%$ респондентов хотели бы изменить систему отопления. При благоприятных условиях - постоянное наличие ресурсов, дешевые кредиты на замену системы отопления, субсидии на твердое топливо и активное продвижение древесной биомассы как источника энергии, часть граждан выразила готовность перейти на отопление своего жилья энергетической древесиной. 
Ключевые слова: региональная агломерация; энергетическая древесина; древесные отходы; энергетический потенциал; эколого-экономическая эффективность.

\section{Ecological and economic estimation of the efficiency of energy wood use in the regional agglomeration «Drohobychyna»}

\author{
L. Maksymiv ${ }^{1}$, T. Lutsyshyn ${ }^{2}$
}

Agglomeration is a territorial association of various settlements, connected by economic, labour, social and other aspects. One of the most important areas for establishing close cooperation within the agglomeration is to increase energy efficiency. The feature of the regional agglomeration of "Drohobychyna» is it's belonging to the Carpathian economic region, which is characterized by the highest forest cover in Ukraine, where the local population traditionally uses wood for energy purposes for heating premises and cooking. Accordingly, there is a sufficient amount of wood biomass resources that can and should be used for energy purposes.

The Carpathian region has a significant potential of wood biomass available for energy use by attracting forest wood, wood from landscaping, wood residues from the processing, wood waste. Additional sources of wood fuel can be parks, forest protection strips, energy plantations, afforestation along motorways and railroads, as well as dry land.

Lyudmyla Maksymiv - Member-Correspondent of the Forestry Academy of Sciences of Ukraine, Dr., Associate Professor of the Department of Ecological Economics. Ukrainian National Forestry University, Gen. Chuprynky str., 103, Lviv, 79057, Ukraine. Tel. +38 (032) 39-27-78. E-mail: maksymivl@ukr.net ORCID: https:// orcid.org/0000-0001-5003-0249

Tetiana Lutsyshyn - Master of Environment and Natura Resource Economics. Ukrainian National Forestry University, Gen. Chuprynky str, 103, Lviv, 79057, Ukraine. Tel.: (098) 649 6461 E-mail: tetyana.lutsyshyn@ukr.net ORCID: https://orcid. org/0000-0001-6988-1545
The resource potential of energy wood in the territory of the regional agglomeration of «Drohobychyna» forms the resources of specialized enterprises, where the main suppliers of wood biomass are the State Enterprise «Drohobych forestry», Drohobych State Forestry Enterprise «Galsillis» and potentially the «Green World» Municipal Enterprise in Boryslav. In 2017, the wood increment at the enterprises under consideration was: in the state enterprise «Drohobych forestry» 113.4 thousand $\mathrm{m}^{3}$; Drohobych SFE «Galsillis» 32,2 thousand $\mathrm{m}^{3}$; Municipal Enterprise «Green World» 0.9 thousand $\mathrm{m}^{3}$.

Reserve for increasing of the efficiency of wood utilization are cuttings, the volume of which at State Enterprise «Drohobych forestry» in 2017 amounted to 7,1 thousand $\mathrm{m}^{3}$, and at Drohobych SFE «Galsillis» for the first half of $2018-0,5$ thousand $\mathrm{m}^{3}$. Waste of forestry operations can become an additional resource of wood biomass for use in energy purposes. Another way of producing wood biomass is to grow energy plantations on infertile lands.

To determine the level of readiness of the local population to use wood for the needs of households, as well as factors influencing the energy wood use, a sociological survey of part of the population of Boryslav was conducted, in which 81 respondents participated. The study found that most residents use an individual heating system using gas or combined boilers. It was found that $40 \%$ of respondents would like to change the heating system. Under favourable conditions such as constant availability of resources, cheap loans for replacing the heating system, subsidies for solid fuels and the active promotion of wood biomass as a source of energy, part of citizens expressed their willingness to switch to heating their housing energy wood.

This paper was developed in the framework of Swiss-Ukrainian research project «Identifying of Green Energy options in the Ukrainian Carpathians» under leading of Institute of forest, snow and landscape (WSL), Switzerland, funded by the Swiss Secretariat for Research, Education and Innovation (SBFI) in the framework of the Ukrainian-Swiss Cooperation in Forest Research consists of targeting the usage of wood energy in the Ukrainian Carpathians.

Key words: regional agglomeration; energy wood; wood waste; energy potential; ecological and economic efficiency. 